\title{
Visitor impact assessment and management of Gulmarg tourist area
}

\section{IRFAN NABI BHAT AND FAISAL NABI}

Article Chronicle :

Received :

20.04.2016;

Revised:

02.05.2016;

Accepted :

16.05.2016

Key Words :

Visitor impacts, Tourists,

Ponywallas, Gulmarg development authority
ABSTRACT : The present study was conducted in Gulmarg meadow with an aim to assess visitor impacts and management of this famous tourist resort. During the study a monitoring programme was conducted in the area and questionnaires were distributed among tourists. It was observed that the meadow is receiving negative impacts from over tourism and tourists are not satisfied with the management.

HOW TO CITE THIS ARTICLE : Bhat, Irfan Nabi and Nabi, Faisal (2016). Visitor impact assessment and management of Gulmarg tourist area. Asian J. Environ. Sci., 11(1): 72-77, DOI: 10.15740/HAS/AJES/11.1/72-77.

Author for correspondence :

\section{IRFAN NABI BHAT}

Department of

Environmental Biology,

A.P.S. University, REWA

(M.P.) INDIA

Email : drirfannabi@gmail.

com

See end of the article for

Coopted authors' 